\title{
Janus-Faced Justice? The Role of Legal Technology in the Provision of Access to Justice
}

\author{
Winner of the Best in category, Justis \\ International Writing Competition 2019 for the \\ category Access to Justice and Technology (in \\ partnership with The City Law School), by \\ Eleanor De of City, University of London.
}

The move towards digitisation is a growing global trend and an inescapable reality. But so too is the increasing chasm between rights in law and rights enforced. The advent of legal technology presents exciting opportunities to bridge this gap, but it would be imprudent to assume that this is a symbiotic relationship, or that digitisation necessarily improves access to justice.

New technologies could be used to improve transparency, disseminate legal information, provide access to court decisions and reduce court backlog' and in some places this potential has been realised. In the Netherlands, for instance, an online dispute resolution service (Rechtwijzer) has been developed to help users identify whether their problem involves legal issues, guide them through their rights and explain how to enforce them. This informs the user, empowers them and provides actionable solutions to their problems, whilst also decreasing the burden on the courts and providing ease of access.

However, preoccupation with cost-cutting and efficiency is an enormous barrier to improving access to justice through legal technology. This manifests in several ways.

\section{In situations where legal technology might be the best way to increase access and participation, it might not be the most cost-effective option}

The Consultative Council of European Judges noted in an opinion on justice and information technologies that cost may be both an advantage and a disadvantage ${ }^{2}$. Costs are highly context-specific and it is a misconception that digitisation is necessarily cheaper. This sits at odds with the idea that technology, austerity and access to justice can happily co-exist, and may provide some explanation for the pattern of digitisation that has thus far emerged.

By way of example, the highly lauded Civil Resolution Tribunal in British Columbia, Canada, was borne out of a report that argued that 'court processes...often do not make sense or work for litigants'3. The driving force behind the Canadian reform, therefore, was concern for public access and although financial motivations were part of this, they played a subsidiary role.

By contrast, Smith and Paterson note that the English and Welsh government...is driven much more overtly by $a$ need for savings'4. This may explain why the UK has been slower to adapt to changes in technology and why the bulk of work to date has been on the growth of a paperless system. Other forms of innovation such as digitised public legal education or using technology to synchronise information sharing between services such as $\mathrm{Her}$ Majesty's Courts and Tribunals Service (HMCTS), probation and the NHS would require more investment and have, thus far, taken a back seat.

\section{This can lead to a dichotomous approach}

Earlier this year, HMCTS launched a proposal for a number of court closures, justified on the basis that there is a need to invest in 'wholly new, more convenient, fleeter routes to justice' 5 . This represents a risky binary approach, whereby governments assume that digitisation removes the requirement or demand for traditional faceto-face justice. In light of digital exclusion rates, it is imperative that digital services and traditional mediums are not seen as mutually exclusive. 


\section{The focus on costs results in a lack of consultation with service users which leads to provisions which are not shaped or informed by lived experience and user needs}

A common difficulty in the process of digitisation is a lack of consultation between state and citizen. Moreover, consultation is often retrospective (conducted after policy drafting), and fails engage in the kind of iterative process necessary of such a dialogue.

This leads to practical problems. For instance, there are few opportunities to correct the misconception that the only people who are digitally excluded are those Internet-deprived citizens [who are not] able or willing to use technology when it is first deployed'6. The most vulnerable people experience a multiplicity of issues including - but not limited to - homelessness, poverty, illiteracy and ill mental health. And it is these people who experience the most legal problems and do less about them. Insensitivity to the nuance of digital exclusion then manifests itself in the execution of digital services. For example, more robust consultation with interest groups might have prevented HMCTS from introducing an 'opt-in' system for the Assisted Digital programme (an inappropriate arrangement because many people are unable to make informed decisions about whether the online system is right for them $)^{7}$.

This is also evident in situations where digital services are implemented without the necessary individualised or emotional support. An Australian study reported that there is often an unhelpful focus on the mechanical dissemination of information, regardless of how useful it might be ${ }^{8}$. Similarly, a UK government-produced infographic video on domestic violence was deemed patronising and unhelpful by its intended audience?. In the criminal context, the use of live video link has been contentious, and using it to provide an interpreter for vulnerable people who require an appropriate adult has been heavily criticised for failing to address user needs ${ }^{10}$.

\section{The risk of a breakdown of trust between citizen and state}

People come into contact with legal services at times which are likely to be the most stressful in their lives. It is imperative, therefore, as Tickle notes, that governments remain aware of the possibility of losing the critical quality of human judgment and the ways in which digital pathways can be anonymising and alienating ' '. After all, the legitimacy of the legal system hinges on the public's trust and confidence in the system. In a civil setting, this may lead to further disengagement and in a criminal context, the misuse of technology could impact on recidivism rates; if there is perceived to be a dearth of procedural justice, trust may be eroded which can affect offenders' cooperation with criminal justice institutions in the future.

As long as cost-cutting remains the primary motivator for adopting new legal technologies it is impossible to guarantee improved access to justice. To enact meaningful change, it is essential that user needs are consulted throughout development and implementation, and that the increased drive towards digitisation does not diminish the procedural safeguards necessary for a fair hearing.

\section{Footnotes}

' Julinda Beqiraj and Lawrence McNamara "International Access to Justice: Barriers and Solutions", Bingham Centre for the Rule of Law, October 20l4. https://www.biicl.org/documents/365_20l4_ibatokyo_beqirajmcnamara_internationalaccesstojusticebarriersandsolutions.pdf?showdocument $=$ I (accessed 28th November 2018).

${ }^{2}$ Dory Reiling, "Technology In Courts In Europe: Opinions, Practices And Innovations", International Journal For Court Administration, June 2012 https://www.iacajournal.org/articles/10.18352/ijca.75/galley/57/download/ (accessed 28th November 2018).

${ }^{3}$ Action Committee on Access to Justice in Civil and Family Matters, "Access to Civil and Family Justice: A Roadmap for Change”, October 2013. http://www.cfcj-fcjc.org/sites/default/files/docs/20I3/AC_Report_English_Final.pdf (accessed 28th November 2018).

${ }^{4}$ Roger Smith and Alan Paterson, "Face to Face Legal Services and their Alternatives : Global Lessons from the Digital Revolution”, University of Strathclyde Prints, 2014 ,pg 7. https://www.publictechnology.net/articles/news/hmcts-consults-court-closures-digitisation-programme-rolls (accessed 28th November 2018).

${ }^{5}$ Ministry of Justice and HMCTS, "Fit for the future: transforming the Court and Tribunal Estate", I8th January 2018, https:// consult.justice.gov.uk/digital-communications/transforming-court-tribunal-estate/supporting_documents/hmctsstrategyapproachconsultation.pdf (accessed 30th November 2018).

${ }^{6}$ B R Hough, "Let's not make it worse: issues to consider in adopting new technology", Harvard Journal on Law and Technology, Vol 26 No I, Fall 20I2, p266.

${ }^{7}$ Paul Anders, "Transforming Justice", Revolving Doors Agency, 10th February 2017 http://www.revolving-doors.org.uk/blog/transforming-justice (accessed 28th November 2018). 
${ }^{8} \mathrm{R}$ Hunter, C Banks and J Giddings, 'Technology is the answer ... what was the question: Services to Regional, Rural and Remote Clients', pl46, in P Pleasence, A Buck, N Balmer, "Transforming Lives: law and social process", Legal Services Commission, 2007.

${ }^{9}$ Roger Smith and Alan Paterson, "Face to Face Legal Services and their Alternatives: Global Lessons from the Digital Revolution", 2014.

${ }^{10}$ National Appropriate Adult Network, "Consultation Response DRAFT - Revised PACE Code C (Detention) 2016 Interpreters", NAAN Policy, 2016 http://appropriateadult.org.uk/images/pdf/2016_CodeC_interpreter_response.pdf (accessed 30th November 2018).

"Louise Tickle, "Online justice: why courts should explore emerging digital possibilities", The Guardian, 16th January 2017 https://www.theguardian.com/public-leaders-network/2017/jan//6/online-justice-courts-explore-digital-possibilities (accessed 29th November 2018).

\section{Blurred Lines: Social Media in Armed Conflict}

\section{Winner of the Best in category, Justis International Writing Competition 2019 for the category Social Media, Technology and the Law (in partnership with the Richmond Journal of Law \& Technology), by Iphigenia Fisentzou of BPP.}

Technological advancements have revolutionised the social interactions of global society and in turn influenced the means and methods of warfare; increasing the involvement of civilians in hostilities, not only as victims but also as participants.' Together with the involvement of multiple state and non-state actors, civilian participation makes these modern conflicts all the more unpredictable, challenging inter alia the traditional notion of direct participation in hostilities established under international law.

\section{SOCIAL MEDIA: A MODERN WEAPON}

The first 'internet war' in Kosovo witnessed the utilisation of the internet for the advancement of military operations. $^{2}$ Non-state actors, specifically terrorist organisations, were the first to harness social media networks for the recruitment of followers, the dissemination of information and the gathering of intelligence. ${ }^{3}$ State and inter-state actors have also gradually embraced social media as platforms suited for military operations, ${ }^{4}$ effectively weaponising them through their adaptation and utilisation to 'achieve "military" effects'. ${ }^{5}$

Social networking platforms (Facebook) and microblogging websites (Twitter) are examples of 'social media' enabling social interaction through the creation, collection, sharing and delivery of user-generated content such as photographs and written posts. ${ }^{6}$ Information from social media sites has been used for cyber operations, ${ }^{7}$ as well as for the singling out and targeting of individuals believed to be linked with the opposing parties to a conflict. ${ }^{8}$ "Open source intelligence" has proven instrumental for parties with no boots on the ground of the conflict, 9 